\title{
MANAJEMEN KEPALA SEKOLAH DALAM MENERAPKAN NILAI-NILAI ISLAM DI SD NEGERI 28 RAMBATAN
}

\author{
Suhaili. M \\ Guru SD Negeri 3 Rambatan \\ J orong Buluh Kasok Nagari Tabek, Pariangan, Tanah Datar
}

tosen

\begin{abstract}
This qualitative study analyzed the management of principal on applying Islamic values in Primary School 28 Rambatan. The intruments in this study were interview, observation and documentation. The results showed that the management was done well. The programs applied in this primary school were speech, praying dhuha and praying dzuhur together, making wall magazine, scout, art contest, sport, social activity, and flag ceremony.
\end{abstract}

Keywords: Management, Islamic Values, Primary School 28 Rambatan.

\section{PENDAHULUAN}

Salah satu persoalan pendidikan yang sedang dihadapi bangsa Indonesia adalah persoalan mutu pendidikan pada setiap jenjang dan satuan pendidikan. Berbagai usaha telah dilakukan untuk meningkatkan mutu pendidikan nasional, antara lain melalui berbagai pelatihan dan peningkatan kompetensi guru, pengadaan buku dan alat pelajaran, perbaikan sarana dan prasarana pendidikan, dan meningkatkan mutu manajemen sekolah. Namun demikian, indikator mutu pendidikan belum menunjukkan peningkatan yang berarti (Departemen Agama RI, 2001).

UU No. 20 Tahun 2003 sangat jelas memaparkan bahwa Pendidikan nasional berfungsi mengembangkan kemampuan dan membentuk watak serta peradaban bangsa yang bermartabat dalam rangka mencerdaskan kehidupan bangsa, bertujuan untuk berkembangnya potensi peserta didik agar menjadi manusia yang beriman dan bertakwa kepada Tuhan Yang Maha Esa, berakhlak mulia, sehat, berilmu, cakap, kreatif, mandiri, dan menjadi warga negara yang demokratis serta bertanggung jawab.

Pendidikan dan pembelajaran agama bertujuan mengembangkan dan menanamkan watak berahlak sesuai dengan kerangka normatif agama dan berusaha merubah perilaku seseorang dalam arti luas dan jangka waktu yang lama. Untuk itu, pendidikan dan pembelajaran agama dapat 
berhasil jika siswa ada disposisi batin yang benar (syahadah) untuk menghayati sekaligus melaksanakan akan makna kehidupan yang disinari nilai-nilai ilahiyah dan insaniyah berdasarkan pendidikan agama yang diterima (Muhaimin, 2001).

Ada tiga nilai-nilai Islam yang diwasiatkan Lukman pada anaknya yaitu (1) shalat, (2) amar måruf dan nahi mungkar, (3) bersabar. Inilah nasehat berharga dari Lukman kepada anaknya. Semoga wasiat ini bisa dicontoh pula oleh setiap orang tua. Sebagaimana firman Allah Ta'ala "hai anakku, dirikanlah shalat dan suruhlah (manusia) mengerjakan yang baik dan cegahlah (mereka) dari perbuatan yang mungkar dan bersabarlah terhadap apa yang menimpa kamu. Sesungguhnya yang demikian itu termasuk hal-hal yang diwajibkan (oleh Allah)" (QS. Lukman: 17).

Dalam penghayatan dan pelaksanannya, nilai-nilai tersebut tidak dapat dipaksa dari luar, melainkan masuk ke dalam hati siswa secara lembut ketika hatinya secara bebas membuka diri (self awareness). Dengan demikian, pendidikan dan pembelajaran agama akan bermakna kalau dapat menginternalisasi atau mempribadi pada diri siswa. Di sinilah pentingnya penanaman nilai-nilai agama yang kokoh. Dengan nilai-nilai yang kokoh, maka agama akan tertanam pada diri siswa, yang pada akhirnya akan menjadi kekuatan penggerak untuk melakukan amal shaleh dan akblakul karimah, karena itu adalah nilai-nilai yang diinginkan oleh Islam (Fatah, 2010).
Nilai-nilai agama Islam mendorong ke penguasaan ilmu pengetahuan, seperti adanya anjuran, "jadilah kamu berilmu yang mengajarkan ilmunya ('aaliman), atau belajar (mutáalliman), atau menjadi pendengar (mustamian), dan jangan menjadi kelompok keempat (rabian). Anjuran ini mengingatkan pentingnya menjaga proses dan kegiatan belajar mengajar (Said, 2005).

SD Negeri 28 Rambatan merupakan salah satu lembaga pendidikan tingkat sekolah dasar yang ada di kecamatan Rambatan yang mencoba untuk menerapkan nilai-nilai Islam di sekolah, seperti melaksanakan sholat dhuha tanpa menunggu perintah dari guru, mematuhi guru, dan belajar dengan giat. Kepala Sekolah SD Negeri 28 Rambatan sering mengevaluasi program yang dibuat oleh guru PAI, yaitu supaya terwujudnya nilai-nilai Islam di sekolah dengan cara melibatkan semua guru sebagai pengontrol terhadap semua program yang direncanakan di sekolah, hal ini dilakukan agar tertanamnya nilai-nilai agama sejak dini pada diri siswa-siswi.

Menurut guru PAI SD Negeri 28 Rambatan "SD Negeri 28 Rambatan sudah membuat program yang bertujuan untuk mengaplikasikan nilai-nilai pendidikan agama yang diperoleh siswa di lokal, dan dapat teraplikasi di lingkungan sekolah dengan pengawasan dan pengontrolan dari para guru". Menurut wali kelas VI yang peneliti wawancarai, "para siswa dianjurkan agar menghafal Al-Qur’an, dari sekian siswa 
yang telah menghafal Al-Qur'an memiliki akhlak yang baik. Dari situlah menonjol nilai-nilai agama pada siswa tersebut sehingga dapat diterapkan di sekolah”.

\section{MANAJEMEN}

Kata manajemen menurut Fattah (1996) berasal dari bahasa latin, yaitu kata manus dan agree yang berarti malakukan. Kata-kata itu digabung menjadi kata kerja managere yang artinya menangani. Managere diterjemahkan dalam bahasa Inggris dalam bentuk kata kerja to manage, dengan kata benda dengan management, dan manager untuk orang yang melakukan kegiatan Manajemen. Akhirnya Manajemen diterjemahkan dalam bahasa Indonesia menjadi manajemen atau pengelolaan.

Hasibuan (2004) mendefinisikan manajemen adalah ilmu dan seni yang mengatur proses pemanfaatan sumber daya manusia dan sumber-sumber lainnya secara efektif dan efisien untuk mencapai suatu tujuan tertentu. Sedangkan menurut Terry (2000) mendefinisikan manajemen merupakan suatu proses yang terdiri dari tindakan-tindakan perencanaan, pengorganisasian, menggerakkan dan mengendalikan yang dilakukan untuk menentukan serta mencapai sasaran yang telah ditentukan melalui pemanfaatan sumber daya manusia dan sumber daya lainnya.

Manajemen pendidikan adalah ilmu dan seni mengelola sumber daya pendidikan untuk mewujudkan suasana belajar dan proses pembelajaran agar peserta didik secara aktif mengembangkan potensi dirinya untuk memiliki kekuatan spiritual keagamaan, pengendalian diri, kepribadian, kecerdasan, akhlak mulia, serta ketrampilan yang diperlukan dirinya, masyarakat bangsa dan Negara (Umar, 2004).

\section{KEPALA SEKOLAH}

Secara etimologi menurut kamus besar bahasa Indonesia (Purwadarmita. 1999), Kepala Sekolah adalah orang atau guru yang memimpin suatu Sekolah. Dengan demikian Kepala Sekolah merupakan pihak yang ditunjuk untuk memimpin suatu lembaga pendidikan. Sedangkan secara terminologi, Wahjosumidjo (1999) mengemukakan pengertian Kepala Sekolah adalah sebagai seorang tenaga profesional guru yang diberi tugas untuk memimpin suatu sekolah di mana diselenggarakan proses belajar mengajar " atau" tempat dimana terjadi interaksi antara guru yang memberi pelajaran dan murid yang menerima pelajaran.

Definisi lain tentang pengertian Kepala Sekolah dikemukakan pula dalam buku kendali mutu pendidikan agama Islam (Departemen Agama RI, 2001), yang menyatakan bahwa Kepala Sekolah adalah “orang yang bertugas sebagai pemegang polisi umum dalam menentukan kebijakan di lingkungan Sekolah”. Berdasarkan tugas praktis yang diemban oleh Kepala Sekolah tersebut tergambar bahwa seorang Kepala Sekolah sebagai pemimpin lembaga pendidikan harus dapat mengembangkan 
dan menyalurkan kebebasan berfikir seluruh guru dan perangkat Sekolah yang ada sehingga akan tercipta suasana kerja yang efektif dan efisien. Selain itu Kepala Sekolah juga harus dapat mendorong terjadinya persamaan terdapat dengan sikap saling menghargai dalam menyelesaikan tugas-tugas yang berkaitan dengan saling menghormati dalam menyelesaikan tugastugas yang berkaitan dengan kemajuan lembaga pendidikan (House, 1996, Mulyasa, 2005). Ada beberapa sifat yang diperlukan dalam kepemimpinan pendidikan yang harus dimiliki oleh kepala sekolah, yaitu (1) rendah hati dan sederhana, (2) bersifat suka menolong, (3) sabar dan memiliki kestabilan emosi, (4) percaya kepada diri sendiri, (5) Jujur, adil dan dapat dipercaya, (6) keahlian dalam jabatan (Mulyasa, 2005).

\section{NILAI-NILAI ISLAM}

Nilai pada dasarnya sifat-sifat atau hal-hal yang penting atau berguna bagi kemanusian. Secara filosofis, nilai sangat terkait dengan masalah etika dan biasa juga disebut filsafat nilai yang mengkaji nilai-nilai moral sebagai tolak ukur tindakan dan perilaku manusia dalam berbagai aspek khidupannya. Adapun yang menjadi sumber nilai dalam Islam yakni alquran dan Hadis. Kedua sumber tersebut adalah sumber utama dari kajian tentang nilai-nilai dalam kehidupan umat Islam (Muhaimin dan Mujib, 1993).

Dalam menanamkan nilai-nilai luhur agama Islam sesuai dengan yang terkandung dalam Al-Qur'an yang diajarkan bukan untuk dihafal menjadi ilmu pengetahuan kognitif, tetapi adalah untuk dihayati dan diamalkan dalam kehidupan sehari-hari. Islam adalah agama yang menuntut kepada pemeluknya untuk mengerjakannya sehingga menjadi umat yang beramal saleh (Sihab, 2000).

Substansi nilai merupakan suatu hal yang komplek dan beragam. Nilainilai Islam berdasarkan sumbernya dapat diklasifikasikan menjadi dua macam, antara lain nilai Illahiyah (nash) yaitu nilai yang lahir dari keyakinan (belief), berupa petunjuk dari supernatural atau Tuhan. Nilai yang diwahyukan melalui Rasul yang berbentuk iman, takwa, iman adil, yang diabadikan dalam al-quran. Kudua, nilai Insaniyah (produk budaya yakni nilai yang lahir dari kebudayaan masyarakat baik secara individu maupun kelompok). Nilai ini tumbuh atas kesepakatan manusia serta berkembang dan hidup dari peradaban manusia. Nilai insani ini kemudian melembaga menjadi tradisi-tradisi yang diwariskan turuntemurun mengikat anggota masyarakat yang mendukungnya (Said, 2005).

\section{METODE PENELITIAN}

Peneltian ini adalah bersifat kualitatif. Penelitian kualitatif yaitu prosedur penelitian dengan hasil data deskriptif. Metode kualitatif bertolak dari pandangan fenomenologis, yang mana peneliti berusaha memahami arti peristiwa dan kaitan-kaitannya terhadap orang-orang biasa dalam situasi-situasi 
tertentu (Patilima, 2011) (Emzir, 2011) (Bungin, 2008) (Moleong, 2002) (Budiman, 2002) (Paton, 1990) (Sugiyono, 2005).

Tujuan Penelitian ini adalah 1) untuk menganalisis manajemen perencanaan Kepala Sekolah dalam menerapkan nilainilai Islam di sekolah; 2) untuk menganalisis manajemen pengorganisasian Kepala Sekolah dalam menerapkan nilai-nilai Islam di sekolah; 3) untuk menganalisis manajemen pelaksanaan Kepala Sekolah dalam menerapkan nilai-nilai Islam di sekolah; 3) untuk menganalisis manajemen pengontrolan dan Evaluasi Kepala Sekolah dalam menerapkan nilai-nilai Islam di sekolah. Karakteristik sumber data pada penelitian ini dilihat dari keutamaan objek untuk memperoleh informasi yang lebih objektif. Sumber data dibagi kepada dua bagian, yaitu sumber data primer, yaitu Kepala sekolah pada sekolah tersebut. Sumber data sekunder adalah sebagai data pendukung yang terkait dengan penelitian ini, yaitu para guru, tenaga administrasi (TU), siswa dan wali murid.

Pedoman wawancara yang digunakan adalah berbentuk pertanyaan open ended and probing, yaitu menguraikan poin-poin khusus yang penting yang didiskusikan dengan informan, yaitu kepala sekolah, guru,siswa dan masyarakat. Studi dokumentasi dalam penelitian ini dilakukan terhadap berbagai catatan dan dokumentasi tentang profil dan latar belakang sekolah, data atau dokumen yang berkaitan dengan manajemen Kepala
Sekolah dalam menerapkan Nilai-Nilai Islam di SD Negeri 28 Rambatan.

Pada tahap awal memasuki lapangan, peneliti masih dianggap orang asing, masih dicurigai sehingga informasi yang diberikan belum lengkap, tidak mendalam, dan mungkin masih banyak yang dirahasiakan. Dengan perpanjangan pengamatan ini, peneliti mengecek kembali apakah data yang diberikan selama ini merupakan data yang sudah benar atau tidak. Bila data yang telah diperoleh selama ini setelah dicek kembali pada sumber data asli atau sumber data lain tidak benar, peneliti melakukan pengamatan lagi secara lebih luas dan mendalam sehingga diperoleh data yang pasti kebenarannya. Lamanya perpanjangan pengamatan ini dilakukan sangat bergantung kepada kedalaman, keluasan, dan kepastian data.

\section{HASIL PENELITIAN DAN PEMBAHASAN}

\section{Perencanaan Kepala Sekolah dalam Menerapkan Nilai-Nilai Islam di SD Negeri 28 Rambatan}

Berdasarkan dokumentasi yang diperoleh di SD Negeri 28 Rambatan bahwa perencanaan program dalam menerapkan nilai-nilai Islam diawali dari melihat bakat dan minat siswa. Hal ini terlihat dari hasil wawancara dengan Kepala sekolah, informan secara jelas mengungkapkan sebagai berikut.

Setiap kegiatan Kepala Sekolah di SD Negeri 28 Rambatan, selalu diawali dari perencaan yang tertuang dalam program 
kerja yang dibuat oleh pengurus Kepala Sekolah bersama pembina dan bimbingan Kepala Sekolah. Program kerja tersebut selalu berorentasi pada penerapkan nilai-nilai Islam, dimana sekolah ini berprinsip bahwa dengan menerapkan nilai-nilai Islam, maka prestasi akademik akan mengikuti. Program yang dibuat dibuat diawal semester dengan melihat kepada potensi dan minat peserta didik. Hal ini juga dimaksudkan agar peserta didik merasa betah dan mau menjalankan program yang dibuat bersama. Program yang direncanakan banyak, karena dalam membuat perencanaan itu, dilakukan pengkajian minat dan bakat siswa agar seluruh aspirasinya bisa tertampung dan dapat dikembangkan. Kemudian dilakukan pengelompokan dan pengkajian kembali program yang sesuai dalam menerapkan nilai-nilai Islam serta yang rasanya mampu kita aplikasikan.

\section{Pengorganisasian Kepala Sekolah dalam Menerapkan Nilai-Nilai Islam di SD Negeri 28 Rambatan}

Kepala Sekolah SD Negeri 28 Rambatan dalam membuat program penerapan nilainilai Islam di antaranya adalah sebagai berikut 1) pelaksanaan muhadharoh di sekolah; 2) pembiasaan shalat dhuha dan dzuhur berjamaah; 3) penilaian kebersihan lokal; 4) pembuatan mading sekolah; 5) pramuka; 6) Usaha Kesehatan Sekolah (UKS); 7) kegiatan perlombaan olah raga dan seni; 8) kegiatan sosial dalam bentuk takziyah, menjenguk yang sakit, pengumpulan dana sosial; dan 9) pelaksanaan upacara bendera setiap hari senin.

\section{Pelaksanaan Kepala Sekolah dalam Menerapkan Nilai-Nilai Islam di SD Negeri 28 Rambatan}

Dari beberapa program kegiatan yang terlaksana dalam menerapkan Nilai-nilai Islam dibuat seperti muhadharoh, shalat dhuha, dan shalat dzuhur berjamaah, pembuatan mading, pramuka, perlombaan seni, olah raga, kegiatan sosial, dan upacara bendera. Dalam pemantauan peneliti semua berjalan dengan baik seperti muhadharoh di sekolah, shalat dhuha dan shalat dzuhur berjamaah, pembuatan majalah dinding, pramuka dan upacara bendera. Hal ini menunjukkan adanya antusias yang tinggi dari siswa dan dilakukan sesuai dengan jadwal yang ada, walaupun kekurangan-kekurangan seperti adanya siswa yang sulit diatur dan kualitas majalah dinding yang belum sempurna isinya serta adanya siswa yang terlambat pada pelaksanaan upacara bendera masih perlu mendapat pembinaan dari guru pembina.

Pelaksanaan shalat dhuha dan dzuhur berjamaah dilakukan setiap hari dan pembenahan mading $2 \mathrm{X}$ sebulan, muhadharoh setiap hari jum'at. Hal ini mampu memberikan kontribusi yang positif terhadap penerapan nilai-nilai Islam. Karena dari kegiatan ini mampu melahirkan nilai ketaqwaan kepada Allah, keberanian berbicara di depan umum (jamaah) disiplin, jujur, serta memberikan perubahan pada sikap dan tingkah laku siswa.

Guru penanggung jawab Kegiatan SD Negeri 28 Rambatan selalu bekerja ekstra 
untuk memberdayakan program dalam menjalankannya. Karena guru penanggung jawab merupakan tempat konsultasi bagi guru yang lainnya. Maka dalam pengamatan peneliti, Kepala Sekolah SD Negeri 28 Rambatan selalu menjalin komunikasi intensif dengan penanggung jawab dan mendampingi siswa dalam setiap kegiatannya sekaligus memberikan masukan-masukan serta motivasi untuk penyempurnaan kegiatan.

Proses ini selalu dilakukan sepanjang hari. Karena diyakini dengan proses yang baik akan menghasilkan apa yang diharapkan untuk membentuk karakter siswa itu. Maka dari itu dalam proses selalu menekankan adanya proses pembiasaan terhadap nilai-nilai yang ditanamkan, sehingga menjadi kepribadian siswa. Seperti apa yang disampaikan oleh Kepala SD Negeri 28 Rambatan bahwa kami tidak mempermasalahkan dimana anak mendapatkan pendidikan, tapi yang terpenting adalah bagaimana proses itu dijalankan. Bentuk nilai-nilai Islam yang ada pada siswa SD Negeri 28 Rambatan adalah sebagai berikut 1) ketaqwaan kepada Allah; 2) keberanian; 3) kemandirian dan kreatifitas; 4) kepedulian sosial; 5) rasa tanggung jawab; 6) saling menghormati dan menghargai; 7) kejujuran; dan 8) sportifitas.

\section{Pengontrolan dan Evaluasi Kepala Sekolah dalam Menerapkan Nilai- Nilai Islam di SD Negeri 28 Rambatan}

Peran guru pembina dan guru-guru lain dalam melakukan pengontrolan program- program yang dibuat oleh Kepala Sekolah sangat penting sekali. Karena dari pelaksanaan kegiatan tentu akan ditemukan kendalakendala. Seperti disiplin anak, motivasi menjalankan program kejujuran ini. Semua perlu bimbingan dan arahan dari pembina dan majlis guru. Sehingga dari kerjasama yang baik yang ditunjukkan oleh majlis guru melalui program kegiatan yang ditetapkan oleh Kepala Sekolah dapat disinergikan dengan program yang dibuat untuk penerapan nilai-nilai Islam.

Dalam menjalankan roda organisasi, Kepala Sekolah melakukan rapat-rapat minimal $1 \mathrm{X}$ sebulan pada ruangan guru yang disediakan oleh sekolah. Dan di dalam rapat tersebut selalu mengevaluasi kegiatan-kegiatan yang dijalankan dan akan dilaksanakan di bawah bimbingan guru pembina. Karena peran guru pembina sangat diharapkan ketika mereka menemukan masalah dalam menjalan program. Guru pembina membantu Kepala Sekolah, mulai dari perencanaan program sampai proses evaluasi serta membantu mengkomunikasikan sumber dana kegiatan kepada kepala sekolah.

\section{KESIMPULAN}

Berdasarkan temuan dapat dikemukakan beberapa kesimpulan sebagai berikut. Perencanaan Kepala Sekolah dalam menerapkan nilai-nilai Islam di SD Negeri 28 Rambatan, selalu diawali dari perencaan yang tertuang dalam program kerja yang dibuat oleh pengurus Kepala Sekolah bersama 
pembina dan bimbingan Kepala Sekolah. Program kerja tersebut selalu berorentasi pada penerapkan nilai-nilai Islam, di mana sekolah ini berprinsip bahwa dengan menerapkan nilai-nilai Islam, maka prestasi akademik akan mengikuti. Program yang dibuat dibuat diawal semester dengan melihat kepada potensi dan minat peserta didik. Hal ini juga dimaksudkan agar peserta didik merasa betah dan mau menjalankan program yang dibuat bersama.

Pengorganisasian Kepala Sekolah dalam menerapkan nilai-nilai islam di SD Negeri 28 Rambatan adalah dengan membuat program penerapan nilai-nilai Islam, maka dibentuk pembina atau penaggung jawab kegiatan. Pelaksanaan nilai-nilai Islam di SD Negeri 28 Rambatan, adalah terdapat beberapa program kegiatan seperti muhadharoh, shalat dhuha, shalat dzuhur berjamaah, pembuatan mading, pramuka, perlombaan seni, olah raga, kegiatan sosial, dan upacara bendera. Dalam pemantauan peneliti semua berjalan dengan baik, walaupun dibeberapa program hanya melihat dokumentasi saja. Tetapi pada program lain dapat peneliti amati sendiri seperti, muhadharoh di sekolah, shalat dhuha dan shalat dzuhur berjamaah, pembuatan mading, pramuka dan upacara bendera.

Pengontrolan dan evaluasi Kepala Sekolah dalam menerapkan nilai-nilai Islam di SD Negeri 28 Rambatan adalah dalam melakukan pengontrolan program-program yang dibuat oleh Kepala Sekolah. Karena dari pelaksanaan kegiatan tentu akan ditemukan kendalakendala. Seperti disiplin anak, motivasi menjalankan program kejujuran ini. Semua perlu bimbingan dan arahan dari pembina dan majlis guru. Sehingga dari kerjasama yang baik yang ditunjukkan oleh majlis guru melalui program kegiatan yang ditetapkan oleh Kepala Sekolah dapat disinergikan dengan program yang dibuat untuk penerapan nilai-nilai Islam.

\section{KEPUSTAKAAN ACUAN}

Budiman, Aris. (2002). Desain Penelitian, Pendekatan Kualitatif \& Kuantitatif. Jakarta: KIKI Press.

Bungin, M. Burhan (2008). Penelitian Kualitatif, Komunikasi, Ekonomi, Kebijakan Publik, dan Ilmu Sosial Lainnya. Jakarta: Kencana

Departemen Agama RI. (2001). Kendali Mutu pendidikan Agama Islam. Cet. ke1. Jakarta: Depag RI.

Emzir. (2011). Analisis Data: Metodologi Penelitian Kualitatif. Jakarta: Rajawali Press.

Fatah, Jalil Abdul. (2010). Ilmu Pendidikan Islam. Jakarta: Amzah.

Fattah, Nanang.(1998) Landasan Manajemen Pendidikan. Bandung. PT. Remaja Rosda Karya.

Hasibuan, Malayu. (2004). Manajemen (Dasar, Pengertian dan Masalah). Jakarta: PT. Bumi Aksara.

House, J. Robert. (1996). "Path-Goal Theory of Leadership: Lessons, Legacy, and a Reformulated Theory". Leadership Quarterly Vol.7 (3), 1996 
Moleong, Lexy J. (2002). Metodologi Penelitian Kualitatif. Bandung: Remaja Rosdakarya.

Muhaimin. (2001). Paradigma Pendidikan Islam. Bandung; PT. Remaja Rosdakarya.

Muhaimin dan Mujib, Abdul. (1993). Pemikiran Pendidikan Islam: Kajian Filosofis dan Kerangka Dasar Operasionalnya. Bandung: Trigenda Karya.

Patilima, Hamid. (2011). Metode Penelitian Kualitatif. (Bandung: CV Alfabeta.

Patton, Michail Quin. (1990). Qualitative Evaluation and Research Method. Newbury Park: Sage Publication.

Purwadarmita, W.JS. (1999). Kamus Umum Bahasa Indonesia. Jakarta: Balai Pustaka.

Said, Agil Husain Almunawar. (2005). Aktualisasi Nilai-Nilai Qur'an dalam Sistem Pendidikan Islam. Ciputat : Ciputat Press.
Sihab, Quraish. (2000). Tafsir Al-Misbah. Jakarta: Lentera Hati.

Sugiyono. (2005). Memahami Penelitian Kualitatif. Bandung: ALFABETA.

Terry, George R. (2000). Prinsip-Prinsip Manajemen. Edisi Bahasa Indonesia. Bandung: PT. Bumi Aksara.

Undang-Undang Nomor 20 Tahun 2003 tentang Standar Nasional Pendidikan

Wahjosumidjo. (1999). Kepemimpinan Kepala Madrasah Tinjauan Teoritik dan Permasalahan. Jakarta: Raja Grafindo Persada. 